\title{
Paleocontinental setting for the Catskill Delta
}

\author{
Dennis $V$. Kent \\ Lamont-Doherty Geological Observatory and \\ Department of Geological Sciences \\ Columbia University \\ Palisades, New York 10964
}

\begin{abstract}
Paleomagnetic data confirm geological evidence for tropical paleolatitudes for deposition of the Catskill Delta and related Old Red deposits in Europe. A tectonic model constrained by paleomagnetic data suggests that the Catskill deposits are the product of the Acadian orogeny of the Northern Appalachians as a complex continent-continent collision between Armorica (Hercynian Europe), Laurentia (cratonic North America) and possibly Gondwana, with the Traveler terrane (central New England and New Brunswick) rotated and compressed in between.
\end{abstract}

\section{INTRODUCTION}

A low latitude setting for deposition of the mid- to lateDevonian Catskill Delta has been inferred from geologic evidence. The evidence indicates a depositional environment with warm to hot temperatures, geographically variable rainfall patterns, relatively high evaporation rates, and generally easterly winds (Woodrow and others 1973). Paleomagnetic data confirm low paleolatitudes for eastern North America in the Devonian and place additional constraints on the paleocontinental configuration during this time.

Figure 1 shows a paleocontinental reconstruction of the Atlantic-bordering continents for the mid- to late-Devonian based on an assessment of available paleomagnetic data from North America, Europe, and the southern continents (chiefly Africa and Australia). The various landmasses are positioned with respect to lines of paleolatitude according to averages of the individual paleomagnetic determinations. Paleolongitude is not known. Consequently, the relative positions of the landmasses are based on a variety of indirect criteria including minimum relative motion required to achieve the pre-Atlantic, Pangea configuration (e.g., Bullard and others 1965), geological evidence for the presence or absence of a closed ocean, and avoidance of overlap of older continental basements.

Cratonic North America straddled the equator at that time; indeed, paleomagnetic data obtained directly from Catskill rocks indicate southern hemisphere paleolatitudes of only $1^{\circ}$ for exposures in New York (Kent and Opdyke 1978) and $4^{\circ}$ in Pennsylvania (Van der Voo and others 1979). However, now adjacent areas of coastal New England and the Canadian Maritimes were approximately $20^{\circ}$ farther south at this time. For example, metavolcanics in the Boston basin have magnetizations that were reset during the Devonian and indicate a southern hemisphere paleolatitude of about $23^{\circ}$ (Schutts and others 1976). This difference in paleomagnetic directions led to the concept of the Acadia displaced-terrane (Kent and Opdyke 1978; 1979), one of three middle to late Paleozoic terranes now recognized in the Northern Appalachians on the basis of paleomagnetic data.

The Acadia terrane is considered to generally coincide with areas underlain by basement rocks of Avalonian affinity in the Northern Appalachians, including the Avalon Platform of Newfoundland (Kent 1982). The terrane appears to be bounded on the west by large fault zones, such as the Clinton-Newbury, Norumbega-Fredericton, and, with much less certainty, the Cabot Fault in western Newfoundland. Paleomagnetic evidence is compatible with the Acadia terrane reachings its present position with respect to North America by the Carboniferous; the approximately $2000 \mathrm{~km}$ of left-lateral motion required may have been taken up in these fault zones.

Inboard of the Acadia terrane, paleomagnetic data obtained from central Maine and southern Quebec have been interpreted as evidence for a rotated block, referred to as the Traveler terrane (Spariosu and Kent 1983). According to the geographic distribution of paleomagnetic sampling localities and through extrapolation of tectonostratigraphy, the Traveler terrane is thought to encompass a region bounded on the southeast by the Acadian terrane (along the aforementioned faults) and inboard by the Connecticut Valley-Gaspé synclinorium. The proposed Traveler 


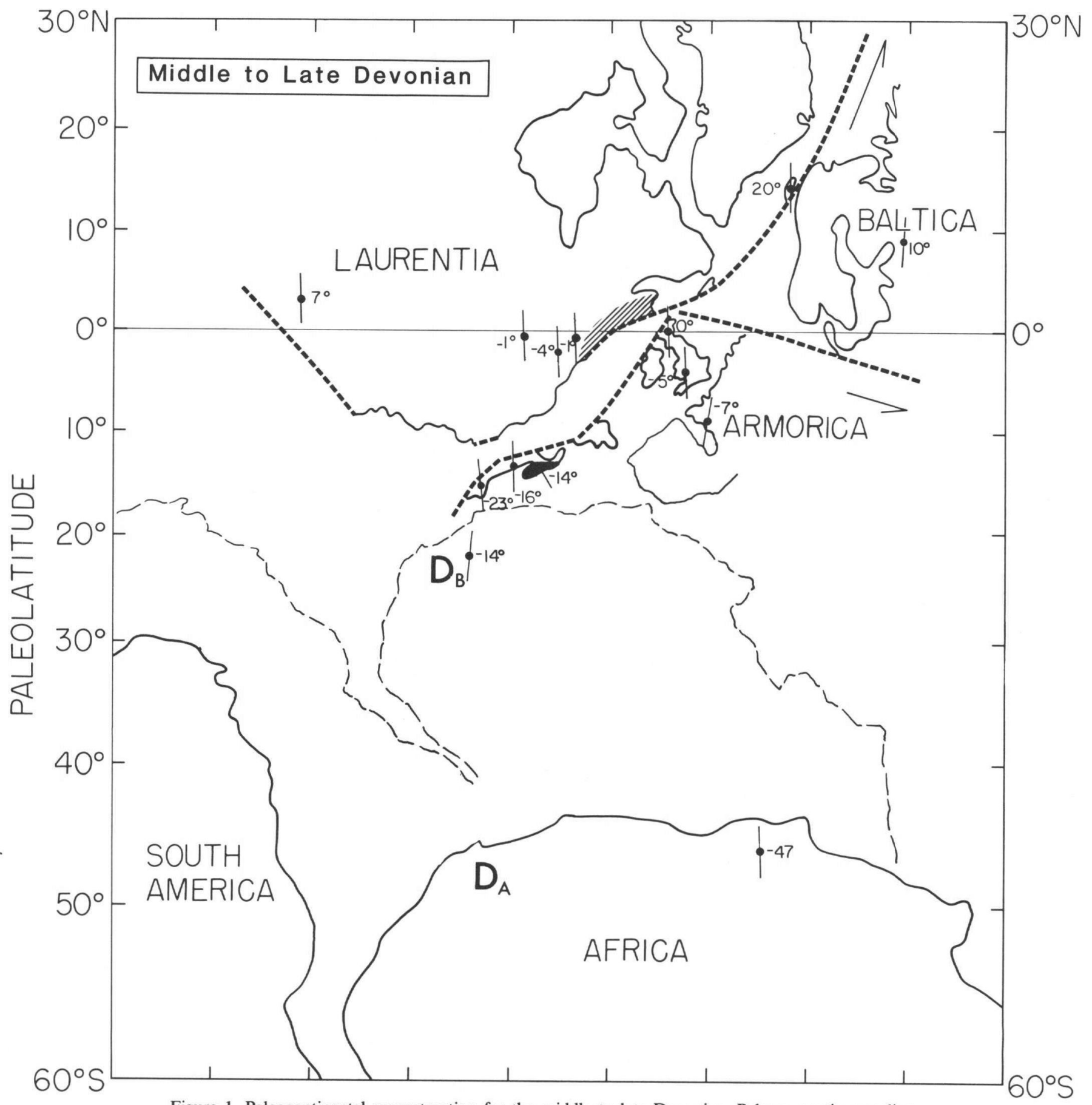

Figure 1. Paleocontinental reconstruction for the middle to late Devonian. Paleomagnetic sampling localities are indicated by filled circles with the intersecting lines showing orientation of paleomeridian and the adjacent numbers referring to calculated paleolatitudes (positive and negative for northern and southern hemisphere, respectively). These data are from the tabulation in Van der Voo and Scotese (1981) with the addition of data from the Gneiguira Formation of Mauritania (Kent and others, 1984), and secondary magnetization (Devonian?) from the Whiterock Formation of southern Nova Scotia (Spariosu and others 1984). Traveler terrane in northern Appalachians indicated by cross-hatchure and the Meguma terrane by dark shading. Position Da for Africa-South America based on paleomagnetic

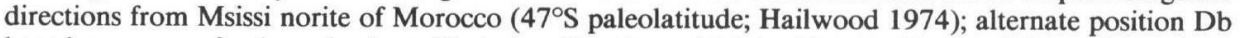
based on mean of paleopoles from Housetop Granite and Mulga Downs Group of Australia, and the Gneiguira Formation of Mauritania (14 ${ }^{\circ} \mathrm{S}$ paleolatitude) (see Kent and others 1984, for discussion of southern continent paleomagnetic data). 
block thus resembles the assemblage of Osberg's (1978) basements B and C, distinct from Laurentian Grenville basement to the west and Avalon basement to the east. The available paleomagnetic data suggest that the Traveler terrane rotated about $20^{\circ}$ clockwise wile converging with cratonic North America during the Devonian, about the same time as Acadian deformation and metamorphism in the New England Appalachians (Spariosu and Kent 1983) and deposition of the Catskill Delta.

Outboard of both the Traveler and Acadia terranes is the third terrane that can be distinguished paleomagnetically, the Meguma of southern Nova Scotia. Although lithostratigraphic evidence strongly suggests that the Meguma was exotic to North America in the early Paleozoic (Schenk 1971; 1978), paleomagnetic data indicate that the Meguma experienced motion relative to North America even in the later Paleozoic. Recently obtained paleomagnetic results (Spariosu and others 1984) indicate that the Meguma was situated at about the same paleolatitude as Acadia, but also rotated approximately $20^{\circ}$ counterclockwise in the Carboniferous to achieve its present position with respect to the inboard areas of North America.

Two of the three terranes identified as displaced on the basis of paleomagnetic data are composites, that is, assemblages of earlier terranes on the basis of tectonostratigraphic similarities and distinctions (Williams and Hatcher 1982; Keppie in press) According to Keppie (in press) the Acadia terrane is a composite of various Late Precambrian and early Paleozoic terranes that were successively added to the core of the Avalon. The Traveler terrane is similarly regarded as a composite of older terranes (e.g., Chain Lakes, Bronson Hill) that may themselves be composites. The amalgamations of the Acadia and Traveler terranes occurred, for the most part, in the early Paleozoic and tend to be associated with major deformational events recognized in the region, such as the Late Precambrian Cadomian, Late Cambrian-Early Ordovician Penobscot, and the Middle to Late Ordovician Taconic orogenic events. Unfortunately, there are few paleomagnetic data available to document the relative motions of terranes involved in most of these earlier amalgamation events. Instead, the presently available paleomagnetic data are primarily sufficient only to constrain relative motions of the composite terranes for the Devonian and younger time intervals.

In summary, the sequence of paleomagnetically-defined displacement in the Northern Appalachians is a clockwise rotation of the most inboard terrane (Traveler) in the Devonian, followed by a northward translation of both the Acadia and Meguma terranes and a counterclockwise rotation of the Meguma. The earlier rotation of the more inboard Traveler terrane can be associated spatially and temporally with the Acadian orogeny; the later northward translation of Acadia and the counterclockwise rotation of Meguma may be associated with an early phase of the Alleghanian orogeny.

\section{PALEOCONTINENTAL RECONSTRUCTION}

The significance of these postulated middle to late Paleozoic tectonic displacements in the northern Appalachians can be considered in the context of their circum-Atlantic paleocontinental setting. In the middle to late Devonian, paleomagnetic pole positions from Armorica (southern Britain, France, and Spain; Van der Voo 1982) and Baltica (Scandinavia and the Russian Platform) agree with those from Acadia (taking into account the opening of the Atlantic), but together are systematically displaced with respect to coeval paleopoles from cratonic North America. Thus Acadia apparently was not a separate plate or microcontinent by the Devonian; rather, it was part of eastern Euramerica, all of which was some $2000 \mathrm{~km}$ farther south with respect to western Euramerica (Laurentia) (Figure 1). The fault systems separating eastern and western Euramerica mostly lie in the Appalachians of New England and Maritime Canada but may include the Great Glen of northern Scotland (Van der Voo and Scotese 1981).

An interesting result of this offset between eastern and western Euramerica is that it brings many of the various Old Red deposition sites on the European side into lower, more equatorial paleolatitudes, such as those of the Catskill, than would be the case in a conventional Pangea juxtaposition (e.g., Bullard and others 1965).

Much uncertainty exists in the position of the facing margins of Gondwana (northern South America and Africa). A paleopole position from the Msissi norite of Morocco, cited as of Late Devonian (Famennian) age by Hailwood (1974), suggests that these facing margins were at high paleolatitudes (Da in Figure 1). Consequently, a wide ocean between the northern (Euramerican) and southern (Gondwanan) continental blocks is implied in the Devonian. Alternatively, recent paleomagnetic results from the Devonian Gneiguira sandstones of Mauritania suggest lower paleolatitudes for the facing margins of South America-Africa at this time (Kent and others 1984). Acceptance of these latter data leads to the conclusion that the ocean between the northern and southern continents was very small or effectively closed by some time in the Devonian ( $\mathrm{Db}$ in Figure 1). Due to ambiguities in determination of the age of magnetization of virtually all midPaleozoic paleomagnetic data from Gondwana (discussed in Kent and others 1984) it is not yet possible to resolve which of the two Devonian positions for Gondwana illustrated in Figure 1 is more nearly correct.

\section{PALEOMAGNETIC TECTONIC MODELS}

The paleocontinental reconstruction shown in Figure 1 is applicable to the period after the Acadian (late Caledonian) orogeny and prior to the climatic Alleghanian (Hercynian) orogeny. On the basis of available paleomagnetic data for the preceding and succeeding time periods, it is possible to suggest how the Devonian configuration shown in Figure 1 might have been achieved and how it evolved into a Pangean assembly by the end of the Paleozoic. The paleocontinental frameworks for the Acadian and Alleghenian orogenies may thus be outlined.

After the Cambrian but prior to the Devonian, paleomag- 
netic evidence suggests that Armorica was a separate plate (Van der Voo 1979). Late Precambrian and early Paleozoic data match between Gondwana and Armorica and are thus compatible with them being adjacent and moving in unison (Hagstrum and others 1980). Results from Armorican parts of France and Spain indicate that this area was close to or connected with Baltica by the late Devonian but, according to position Da (Figure 1), was separated by a wide ocean from Gondwana (Jones and others 1979; Van der Voo 1982).

Originally, Van der Voo (1979) argued that Armorica collided with Laurentia during the Ordovician and gave rise to the Taconic orogeny. Alternatively, the available paleomagnetic data are also consistent with a collision between Armorica and Laurentia in the Devonian to account for the Acadian orogeny (Kent 1980). New paleomagnetic data for the Late Ordovician and Devonian of Armorica now show that Armorica did not collide with the northern continents at the time of the Taconic orogeny but instead did so at the time of the Caledonian or Acadian orogeny (Perroud and others 1983).

In the reconstruction shown in Figure 1, the docking position of Armorica is adjacent to the Traveler terrane in the northern Appalachians (with the outboard areas of eastern Massachusetts, Maine, New Brunswick, Nova Scotia and Newfoundland far to the south at this time). It is therefore possible to conceive of the Acadian orogeny as reflecting a complex continent-cntinent collision between Armorica and Laurentia with the Traveler block compressed and rotated in between. The voluminous Catskill deposits in North America and related Old Red deposits on the European side are likely the products of the erosion and uplift that resulted from this collision.

Euramerica was essentially assembled in the aftermath of the Acadian or Caledonian orogeny. However, apparently as the result of the progressive impingement of the African craton (Lefort and Van der Voo 1981), it was to undergo an internal rearrangement, principally along a sinistral megashear that appears to follow Acadian-Caledonian trends from New England through Newfoundland, Scotland and into Spitzbergen (Harland 1969; Watts 1983). Whether or not the Meguma, the most outboard terrane in the Appalachians, was once part of Africa remains to be verified by paleomagnetic data but its inferred counterclockwise rotation (Spariosu and others 1984) is consistent with its involvement within the hypothesized left-lateral megashear zone. The culmination of the collision of west Africa with North America seems to account for Alleghanian thrusting and faulting in the southern Appalachians (e.g., Cook and others 1981), after the Acadia promontory translated northward out of the direct path of collision.

\section{DISCUSSION}

It is important to point out that not all paleomagnetic data fit neatly into the interpretation of paleocontinental positions presented here. For example, controversy exists regarding the significance of numerous but generally aberrant paleopoles ob- tained primarily from igneous intrusions of mid-Paleozoic age from the northern Appalachians (see Discussion and Reply in Roy 1982; Kent and Opdyke 1982). Since the establishment of terrane displacements depends on the reliability of paleomagnetic data from the suspected terrane as well as reference paleopoles from the cratonic area, it follows that tectonic interpretations will need to be modified if either set of paleomagnetic data is shown to be erroneous. In this regard, Roy and Morris (1983) have recently suggested that the inferred difference in paleolatitude between cratonic North America and the Acadia terrane is due to an artifact of selective remagnetization, not the result of tectonic displacement. New paleomagnetic data from Carboniferous rocks from cratonic North America (e.g. Irving and Strong 1984; Kent and Opdyke, in press) now indicate that any significant tectonic offset of Acadia (as well as eastern Euramerica) with respect to Laurentia or western Euramerica was resolved by the early Carboniferous. Whether any offset existed in the late Devonian, as shown in Figure 1, is critically dependent on the reliability of the paleomagnetic results from the Catskill Formation, which include dual polarities and a positive fold test as evidence for an original magnetization (Van der Voo and others 1979). In any case, the postulated rotation of the Traveler terrane or of the Meguma terrane is still supported although it is conceivable that the northward translation of Acadia may turn out to have occurred in the Devonian and was perhaps associated with the Acadian orogeny.

Clearly, additional paleomagnetic data are needed to verify the paleocontinental positions and tectonic models outlined here. In addition to the problems mentioned above, adequate paleomagnetic data are still lacking for certain other areas and time intervals so that the paleopositions of some of the major continental blocks remain to be verified in critical intervals, for example, Gondwana from the Ordovician to the Early Carboniferous. There is a general consensus that Euramerica occupied low paleolatitudes in the mid-Paleozoic but exactly how Pangea was assembled and exactly how this might be related to major orogenic activity in plate tectonic terms remains a matter for future research. Acquisition of paleomagnetic data to refine the paleocontinental tectonic framework for the Ordovician Taconic orogeny, which might have been the time of assemblage of smaller, perhaps far-travelled terranes along an active continental margin of eastern North America, is also likely to provide important constraints for models of succeeding tectonic events in the circumAtlantic region.

\section{ACKNOWLEDGMENTS}

Support for this work provided by the National Science Foundation, grant EAR82-12549. 


\section{REFERENCES CITED}

Bullard, E. C., Everett, J. E., and Smith, A. G., 1965, A symposium on Continental Drift. IV. The fit of the continents around the Atlantic: Philosophical Transactions of the Royal Society of London, v. A258, p. 41-51.

Cook, F. A., Brown, L. D., Kaufman, S., Oliver, J. E., and Petersen, T. A., 1981, COCORP seismic profiling of the Appalachian orogen beneath the coastal plain of Georgia: Geological Society of America Bulletin, v. 92, p. 738-748.

Hagstrum, J. T., Van der Voo, R., Auvray, B., and Bonhommet, N., 1980, Eocambrian-Cambrian palaeomagnetism of the Armorican Massif, France: Geophysical Journal of the Royal Astronomical Society, v. 61, p. 489-517.

Hailwood, E. A., 1974, Palaeomagnetism of the Msissi Norite (Morocco) and the Palaeozoic Reconstruction of Gondwanaland: Earth and Planetary Science Letters, v. 23, p. 376-386.

Harland, W. B., 1969, Contribution of Spitsbergen to understanding of tectonic evolution of North Atlantic Region, in M. Kay, ed., North Atlantic: geology and continental drift: American Association of Petroleum Geologists Memoir 12, p. 817-851.

Irving, E. and Strong, D. F., 1984, Paleomagnetism of the Early Carboniferous Deer Lake Group, western Newfoundland: no evidence for midCarboniferous displacement of "Acadia": Earth and Planetary Science Letters, v. 69 , p. $379-390$.

Jones, M., Van der Voo, R., and Bonhommet, N., 1979, Late Devonian to Early Carboniferous Paleomagnetic Poles from the Armorican Massif, France: Geophysical Journal of the Royal Astronomical Society, v. 58, p. 287-308.

Kent, D. V., 1980, Formation of Euramerica in the Paleozoic (abs.): EOS, v 61, p. 220.

- 1982, Paleomagnetic evidence for post-Devonian displacement of the Avalon Platform (Newfoundland): Journal of Geophysical Research, v. 87, p. 8709-8716.

Kent, D. O., and Opdyke, N. D., 1978, Paleomagnetism of the Devonian Catskill Redbeds: Evidence for motion of coastal New England Canadian Maritime region relative to Cratonic North America: Journal of Geophysical Research, v. 83 , p. $4441-4450$.

- 1979, The Early Carboniferous paleomagnetic field of North America and its bearing on tectonics of the northern Appalachians: Earth and Planetary Science Letters, v. 44, p. 365-372.

- 1982, Paleomagnetism of Siluro-Devonian rocks from eastern Maine: Reply: Canadian Journal of Earth Sciences, v. 19, p. 232-237.

- Multicomponent magnetizations from the Mississippian Mauch Chunk Formation of the Central Appalachians and their tectonic implications: Journal of Geophysical Research, in press.

Kent, D. V., Dia, O., and Sougy, J.M.A. 1984, Paleomagnetism of Lower-Middle Devonian and Upper Proterozoic-Cambrian(?) Rocks from Mejeria (Mauritania, West Africa: American Geophysical Union Geodynamics Series, v. 12 , p. 99-115.

- in press, Multicomponent paleomagnetic directions from the Mississippian Mauch Chunk Formation of the central Appalachians and their tectonic implications: Journal of Geophysical Research.

Keppie, J. D., in press, The Appalachian Collage, in D. G. Gee and B. Sturt, eds., The Caledonide Orogen, Scandinavia and Related Areas: New York: John Wiley and Sons.

LeFort, J-P. and Van der Voo, R., 1981, A Kinematic model for the collision and complete suturing between Gondwanaland and Laurussia in the Carboniferous: Journal of Geology, v. 89, p. 537-550.

Osberg, Ph.H., 1978, Synthesis of the geology of the north eastern Appalachians, U.S.A., in IGCP Project 27, Caledonian-Appalachian Orogen of the North Atlantic Region: Geological Survey of Canada, Paper 78-13, p. 3-11.

Perroud, H., Van der Voo, R., and Bonhommet, N., 1983, Timing of the Paleozoic drift of the Armorica plate on the basis of new palaeomagnetic results: EOS American Geophysical Union Transactions, v. 64, p. 218.

Roy, J. L., 1982, Paleomagnetism of Siluro-Devonian rocks from eastern Maine: Discussion, Canadian Journal of Earth Sciences, v. 19, p. 225-232.

Roy, J. L., and Morris, W. A., 1983, A review of paleomagnetic results from the
Carboniferous of North America; the concept of Carboniferous geomagnetic field horizon-markers: Earth and Planetary Science Letters, v. 65, p. 167-181.

Schenk, P. E., 1971, Southeastern Atlantic Canada, Northwestern Africa, and continental drift: Canadian Journal of Earth Sciences, v. 8, p. 1218-1251.

- 1978, Synthesis of the Canadian Appalachians: in IGCP Project 27, Caledonian-Appalachian Orogen of the North Atlantic Region: Geological Survey of Canada paper 78-13, p. 111-136.

Schutts, L. D., Brecher, A., Hurley, P. M., Montgomery, C. W., and Krueger, H. W., 1976, A case study of the time and nature of paleomagnetic resetting in a mafic complex in New England: Canadian Journal of Earth Sciences, v. 13, p. 898-907.

Spariosu, D. J., and Kent, D. V., 1983, Paleomagnetism of the Lower Devonian Traveler Felsite and the Acadian orogeny in the New England Appalachians: Geological Society of America Bulletin, v. 94, p. 1319-1328.

Spariosu, D. J., Kent, D. V., and Keppie, J. D., 1984, Late Paleozoic Motions of the Meguma Zone, Nova Scotia: New Paleomagnetic Evidence: American Geophysical Union Geodynamics Series, v. 12, p. 82-98.

Van der Voo, R., 1979, Paleozoic assembly of Pangea: a new plate tectonic model for the Taconic, Caledonian, and Hercynian orogenies: EOS, American Geophysical Union Transactions, v. 60, p. 241.

- 1982, Pre-Mesozoic Paleomagnetism and Plate Tectonics: Annual Review of Earth and Planetary Science, v. 10, p. 191-220.

Van der Voo, R. and Scotese, C., 1981, Paleomagnetic evidence for a large $(2,000$ $\mathrm{km}$ ) sinistral offset along the Great Glen fault during Carboniferous time: Geology, v. 9, p. 583-589.

Van der Voo, R., French, A. N., and French, R. B., 1979, A paleomagnetic pole position from the folded Upper Devonian Catskill redbeds, and its tectonic implications: Geology, v. 7, p. 345-348.

Watts, D. R., 1983, Further Lower Carboniferous Paleomagnetic Results from the Billefjorden Region of Spitzbergen: EOS, v. 64, p. 216.

Williams, H. and Hatcher, R. D. Jr., 1982, Suspect terranes and accretionary history of the Appalachian orogen: Geology, v. 10, p. 530-536.

Woodrow, D. L., Fletcher, F. W., and Ahrnsbrak, W. F., 1973, Paleogeography and paleoclimate at the deposition sites of the Devonian Catskill and Old Red Sandstone Facies: Geological Society of America Bulletin, v. 84, p. 3051-3064.

MANUSCRIPT SUBMITTED JUNE 3, 1983

ReVISEd MANSCRIPT SUBMITTEd February 10, 1984

MANUSCRIPT ACCEPTED BY THE SOCIETY JULY 20, 1984 
Downloaded from specialpapers.gsapubs.org on June 30, 2014

Printed in U.S.A. 